\title{
REVIEW
}

\section{Population Change vs Natural Geography in Asia: A Sociological Ap- praisal}

\section{Mohammad Taghi Sheykhi*}

Professor Emeritus of Sociology, Alzahra University, Tehran, Iran

\begin{tabular}{ll}
\hline ARTICLE INFO & ABSTRACT \\
\cline { 3 - 3 } $\begin{array}{l}\text { Article history } \\
\text { Received: } 5 \text { February } 2021\end{array}$ & $\begin{array}{l}\text { Population is a phenomenon ever changing more positively rather than the } \\
\text { vice versa. It is more increasing in Asian countries. The increase of popula- } \\
\text { tion in Asia is not compatible with the geographical size and capacity of the } \\
\text { countries concerned. Through the process of urbanization, and in the form } \\
\text { of migration, a large number of people have left their birth lands for cities } \\
\text { and new lands. Such a change over contributes to overpopulation, pollution } \\
\text { Published Online: } 31 \text { March 2021 }\end{array}$ \\
\hline Keywords: & $\begin{array}{l}\text { and environmental issues in the new areas and under population in birth } \\
\text { lands; villages and cities. Such a transition creates complex issues in the } \\
\text { new destinations which are sociologically worth appraising. }\end{array}$ \\
Housing problems &
\end{tabular}

\section{Mini Review Article}

The present research appraises how population is rapidly increasing in Asian countries while the size and geography of such countries do not change. This emerging controversy has led to increasing socio-environmental complexities and issues in such places. Population change is a man-made phenomenon, and under the influence of science and technology. On the other hand, overpopulation in countries causes natural resources to change and become industrial-related. Such a conversion is currently occurring in many Asian countries lead to lots of geographical and human problems so far as their food, water and oxygen are concerned. Because of such geographical and demographic change, many people are in great trouble

*Corresponding Author:

Mohammad Taghi Sheykhi,

Professor Emeritus of Sociology, Alzahra University, Tehran, Iran; Emails:mtshykhi@alzahra.ac.ir;mtshykhi@yahoo.com in such countries. The gap between the two contributes to further urbanization and increasing crowdedness of cities. Such a situation has led to increasing price of housing followed by delayed marriages, ever-lasting singlehood, and cohabitation which is recognized unethical and unlawful in some countries. The existing situation has driven many younger people to social, economic and demographic changes. While generation gap was not much observable in the past, in modern time, it is considerably observable. New generations in cities are widely educated, and prone to more education which are drivers of further change. The given transition has contributed to a wide range of norms and values of people in the existing cities in many Asian countries. Such transitions need sociological assessments and analyses, as population being changeable and 
the geography being stable. However, social engineering or sociology provides policy-makers with updated awareness to decide how to engineer their countries. To do the present research, various paradigms were used to find out the facts and figures necessary.

Speed of industrialization followed by gradual urbanization highly affects population growth rate. So, when population migrates to cities, urban culture is learnt and used. We currently see many cities with high population density, which are facing increasing prices, increasing economic inflation, changing cultural values and the like. Asia with a size of about 44 million $\mathrm{km} 2$, as the largest continent of the world is also having 4.6 billion population ${ }^{[12]}$. Under the circumstantial movement of people, the natural geography of Asia has widely changed - many parts of which are not used, and remained dead. Many of the Asian countries such as Bangladesh, India, the Philippines, Vietnam, Thailand, Pakistan, China and Sri Lanka are among the countries being affected by the extreme risk of climate change ${ }^{[11]}$. Since late 1990s the economies of both China and India have been growing rapidly in Asia with an average annual growth rate of more than $8 \%{ }^{[4]}$. The economic growth of these populous countries was accompanied by educational growth of younger cohorts--lowering population growth rate not only in China and India, but other countries in the continent followed suit as well. Such a change also affected many socio-cultural norms and values in the region. Though Total Fertility Rate (TFR) is the age range 15-44, yet education continuation in cities has increased from age 15 up to the ages 27-30, or upper, where fertility is lowered, and fewer children are born within young generations. It is worth mentioning that in less developed countries, TFR is as high as 5 children for a woman, whereas this variable is 2 or even less in developed countries. In other words, shortage of doctors, nurses, hospitals and medicine play a determining role in increasing the children born in some parts of Asia. Population policies are indicative of population change. Demography as the study of population statistics comprising of birth rates, death rates and migration rates, all such statistics are investigated through censuses and surveys conducted in geographies over a period of time ${ }^{[9]}$. Population policies are the active measures to reduce the birth numbers. One-child policy in China between 19792014 prevented about 600 million babies to be born in that country ${ }^{[2]}$. Increasing education also widely affects child birth as a population policy in countries/geographies.

\section{Economics and Resources}

This discusses the relationship between supply and demand and the allocation of natural resources. Economists study the sources of communication between economic and natural systems; With the aim of achieving an efficient and sustainable economy. Hence, from the perspective of economic sociology, there is a significant relationship between economics and resources. Also, population size, population growth trend and density must always be related to resources in its general sense and natural resources in its specific meaning. While population growth increases in the form of geometric progression ${ }^{[1,2,4,8]}$, resource growth occurs in the form of arithmetic progression ${ }^{[1,2,3,4,5]}$ If there is a gap between demographic variables and resources in the general sense, one should expect challenges, contradictions and weaknesses in the coming years and over time.

The trend of increasing life expectancy and declining population in Japan, for example, has led to economic proportions and resources or territory in that society. If Japan increased its population more than it does now, it would face more resource constraints. For this reason, in order to create a balance between population and resources, since the 1950s, it has always adapted population, fertility, manpower, and population growth in general. In this way, by creating such a proportion, a high level of productivity has been achieved and as a result, the GDP has increased. This situation has led to more economic progress in a continuous and sequential manner. Therefore, other countries should always use the economic and social plans and policies and conserve the resources of other countries, including Japan. According to Weismann's theory or worldview, a world with a smaller population and a wider nature makes the connection between the economy and the land smoother. Hence, and from the point of view of economic sociology, the relationship between these two variables must always be considered. More developed societies generally maintained this proportion during the twentieth century and subsequently achieved a more advanced economic position. However, less developed countries, which did not respect the relationship between population and resources, face economic weaknesses and the resulting turmoil. They have become. While the world's population will reach ten billion or more by the end of the 21 st century, the gap between means and ends remains unfilled. This means that predetermined goals cannot be achieved. Therefore, in order to achieve economic development, resources must always be provided. Economic development in addition to providing manpower, its natural resources must be provided in a sustainable way. Otherwise, economic development will not be achievable. Therefore, in order to access resources, the agricultural sector as a supporter of industrial production must always be stable and active. 
In the absence of adequate oversight of primary resources and the agricultural sector being overshadowed by industrial development and the expansion of urban geographical areas, this move itself will face economic expansion with obstacles to raw materials. Countries like China and India today in Asia have given high priority to their agricultural sector to advance their industrial and economic goals. Japan with its economic characteristics; this means that the third country in the world in terms of GDP, the fourth country in terms of purchasing power parity and the second most developed country in the world must always provide the necessary economic resources. The industrial and economic management of that country actively procures and supplies raw materials and resources from different parts of the world; simply because the cycle of economic production in different parts of the country does not stop. Japan's economic and industrial policy mission is to test and diligently rebuild its economic and industrial systems; in order to ensure the bright future of the country ${ }^{[3]}$. Thus, as much as manpower is important in the economy, raw materials will be just as important. Not only Japan but other industrialized nations have followed suit throughout the twentieth century. Although manpower has dwindled in many industrialized countries during the twentieth century, it has itself been provided through the reception of migrant workers. But at the same time, the supply and supply of raw materials from other parts of the world has continued, and continues to continue.

Severe dependence on imported fuel resources and declining human resources has created economic challenges for that country (Japan). While even Japan has faced challenges with all its calculations, futures, and continuous monitoring of demographic indicators; That is, an increase in the elderly population on the one hand, and a shortage of manpower on the other, other less developed countries will naturally face more challenges and turmoil.

While Japan is making tremendous use of advanced technologies that replace manpower, it is still facing a shortage of manpower. Japanese industrial companies are always looking to retain their personnel in the labor market, and that is due to the shortage of manpower and increasing aging in that country ${ }^{[6]}$. In order to provide it, it must always provide appropriate policies that are appropriate to the situation. For example, because the manpower shortage is so palpable in that society, and on the other hand, the elderly and parents also provide direct services to their working children, this country has recently turned the work of many women in that society into part-time. So that such manpower can play their caring role as well as their caring role. Also, in order to provide manpower, it has assigned two to three jobs to many employees in order

to fill the manpower gap as much as possible. Therefore, the labor and manpower planning system must always and flexibly formulate and use newer policies and plans.

There seems to be a demographic-economic paradox in Asia. There is an inverse relationship between population and economy within and between nations. Population growth, high population size, high fertility rate and factors such as these greatly affect economic frameworks, so that the supply of labor and employment is not commensurate with the population seeking work and the skilled people. The demographic-economic paradox is described as nations and populations with high GDP per capita are those with fewer children (1). This paradox or demographic-economic interaction is seen in most developing Asian countries today. Therefore, developing countries should always have control over their population trends such as fertility, range of fertility, number of births, population migration from rural and agricultural sectors to industrial and service sectors. Otherwise, the mentioned paradox becomes more and more objective and apparent, which has its own economic and social consequences and challenges.

Table 1. Total fertility rate in Southeast Asia 2016 (Average number of live births for a woman)

\begin{tabular}{cc}
\hline Country Name & Total Fertility Index \\
\hline Singapore & 1.2 \\
Thailand & 1.5 \\
Brunei & 1.8 \\
Vietnam & 2 \\
Myanmar & 2.2 \\
Indonesia & 2.4 \\
Philippines & 2.5 \\
\hline
\end{tabular}

Source: Statista, ${ }^{[10]}$.

In proportion to the increase in literacy and per capita (GDP), the number of children has decreased, especially in industrial societies. This means that following the literacy of women and their entry into the labor market, birth rate has gradually declined, and on the other hand, following the per capita increase in GDP, or in other words, per capita income, the economic way of life and the social strata have been affected. Consequently, families' lifestyles and their expectations largely led families to less fertility. This trend has continued over the past 70 years, and is still ongoing. This has caused many societies even face a shortage of manpower. According to the Indian Minister of Population Karan Singh in 1974- Conference in Bucharest (Romania), development is the best means of population prevention. Countries that achieve economic development, gradually become more disciplined. 


\section{References}

[1] Balan, F. (2015). Testing the Demographic-Economic Paradox for Newly Industrialized Countries: A Panel Data Analysis, Economic Insights-Trends and Challenges, Vol. IV, No. 2/ 2015, Turkey.

[2] Bongaarts, J. (2016). Slow Down Population Growth, Macmillan Publisher Limited.

[3] Economic and Industrial Bureau, (2005), Necessity of Economic Structural Reform, The Dream Gate Project, Japan.

[4] Farah, P. D. (2006). "Five Years of China WTO Membership, SSRN.

[5] Hayes, (2015), Population and Resources, Australian Institute of International Affairs, Australian Outlook.
[6] Nussey, S.( 2017), Japanese Companies Struggle to Hire, Retain Staff as Labor Shortage Worsens, Reuters, Business News.

[7] Population Reference Bureau's Population Handbook, (2011), Sixth Edition, Washington DC.

[8] Population, Retrieved, (2020).

[9] PRB Hnadbook of Population, (2011), 4th International Edition, Washington DC.

[10] Statista, (2016), Total Fertility Rates in Southeast Asian Countries.

[11] Which Countries Are Most Threatened by and Vulnerable to Climate Change? Retrieved 17 Dec. 2020.

[12] World Population Data Sheet, (2020), Population Reference Bureau, Washington DC. 